\title{
ISOLATION AND MAPPING OF MICROSATELLITES FROM A LIBRARY MICRODISSECTED FROM THE WERNER SYNDROME REGION, 8p11.2-p22
}

\author{
Keiko Nagano, ${ }^{1}$ Jun Nakura, ${ }^{1}$ Koichi Kihara, ${ }^{1}$ Lin Ye, ${ }^{1}$ \\ Kouzin Kamino, ${ }^{1}$ Noriaki Mitsuda, ${ }^{1}$ Tohru Ohta, ${ }^{2}$ \\ Yoshihiro JinNo, ${ }^{2}$ Norio Nirkawa, ${ }^{2}$ Tetsuro Miki, ${ }^{1}$ \\ and Toshio OgIHARA ${ }^{1}$ \\ ${ }^{1}$ Department of Geriatric Medicine, Osaka University Medical School, \\ Yamada-oka, Suita, Osaka 565, Japan \\ ${ }^{2}$ Department of Human Genetics, Nagasaki University School of Medicine, \\ Sakamoto, Nagasaki 852, Japan
}

\begin{abstract}
Summary We have constructed a new genetic linkage map of the Werner syndrome (WRN) region, using microsatellites from a library which was developed by a chromosome microdissection and enzymatic amplification method. These microsatellites were used to genotype members of CEPH families using a simplified detection system of polymerase chain reaction (PCR) products. Two-point analysis was used to assign 4 microsatellite markers relative to each marker and other markers reported in the CEPH public data base. We confirmed that these 4 markers are located to the WRN region, 8p11.2-p22. Such microsatellites microdissected from the definite chromosome region may be useful for positional cloning.
\end{abstract}

Key Words Werner syndrome (WRN), chromosome microdissection, chromosome 8, linkage analysis, microsatellites

\section{INTRODUCTION}

Werner syndrome (WRN) is an autosomal recessive disorder, a progeroid syndrome, characterized by the appearance of features of premature aging in a young adult. Isolation of the WRN gene by positional cloning may give us clues to disclose the mechanisms of aging. We typed more than 20 Japanese WRN patients mainly from first cousin marriage by the homozygosity mapping method (Lander and Botstein, 1987) and confirmed the result reported by Goto et al. (1992) that the WRN locus is located on the short arm of chromosome 8, 8p11.2-p12 (Schellenberg et al., 1992). As a step forward isolating the WRN gene, we have

Received September 13, 1993; Revised version accepted October 29, 1993. 
isolated 7 microsatellite markers from a library developed by the chromosome microdissection and enzymatic amplification method. In this paper we describe the identification and characterization of $4(\mathrm{CA})_{\mathrm{n}}$ repeat polymorphic markers from the WRN region.

\section{MATERIALS AND METHODS}

Chromosome microdissection and construction of plasmid library. The procedure for microdissection and microcloning was described by Hirota et al. (1992) and Kibe et al. (1992). Thirty pieces of an 8p12-p22 region dissected with a threedimensional micromanipulator (Narishige Co., Tokyo) were treated with a proteinase $\mathrm{K}$ solution $(0.5 \mathrm{mg} / \mathrm{ml}$ proteinase $\mathrm{K} / 0.1 \%$ sodium dodecyl sulfate (SDS)/ $10 \mathrm{~mm}$ Tris- $\mathrm{HCl}, \mathrm{pH} 7.5 / 10 \mathrm{~mm} \mathrm{NaCl}$ ) in a siliconized moist chamber, and DNA was extracted by phenol/chloroform treatments. The microdissected DNA was digested with SauBAI and then amplified with the primer-linker PCR method described by Jinno et al. (1992). To confirm the localization of the PCR products, chromosome in situ suppression (CISS) hybridization was performed on metaphase chromosomes using the PCR products as a probe pool (Deng et al., 1992; Hirota et al., 1992). The primer-linker ends of the amplified products were digested with EcoRI, purified by preparative agarose gel electrophoresis and ligated into a pUC18 vector.

Isolation and characterization of $(C A)_{\mathrm{n}}$ microsatellites. E. coli $\mathrm{HB101}$ was transformed by the ligation product on an ampicillin $(50 \mu \mathrm{g} / \mathrm{ml})$ plate, transferred to nylon membranes, and screened for colonies carrying the $(\mathrm{CA})_{n}$ repeat sequences by hybridization with the nick-translated polynucleotides, $(\mathrm{dC}-\mathrm{dA})_{\mathrm{n}}(\mathrm{dG}-\mathrm{dA})_{\mathrm{n}}$ (Pharmacia). Hybridization was performed overnight in $1 \times$ Denhardt's solution, $1 \mathrm{M} \mathrm{NaCl}, 50 \mathrm{~mm}$ Tris-HCl, (pH 7.4), $10 \mathrm{~mm}$ EDTA, $0.1 \% \mathrm{SDS}$, and $0.1 \mathrm{mg} / \mathrm{ml}$ denatured sonicated salmon sperm DNA at $56.5^{\circ} \mathrm{C}$. Filters were washed at room temperature for $30 \mathrm{~min}$ in $6 \times \mathrm{SSC}$ and $0.1 \% \mathrm{SDS}$. Plasmids with strongly hybridizing signals were purified with Magic Minipreps (Promega). Double stranded DNA from each selected plasmid clone was sequenced using the dideoxynucleotide chain termination method with fluorescent primers on an Applied Biosystems 373A DNA sequencer. Primer sequences flanking $(C A)_{n}$ repeats were determined using the OLIGO ver. 4.0 program (National Bioscience Inc.) and oligonucleotides were synthesized using an Applied Biosystems Model 392 synthesizer.

PCR amplification and polymorphism analysis. Genomic DNA from the CEPH families used for genotyping was obtained from the CEPH. Amplifications were performed in a total volume of $10 \mu$ l containing $20 \mathrm{ng}$ of genomic DNA, 20 pmol of each primers, $200 \mu \mathrm{M}$ of each deoxynucleotide triphosphate (dNTP), 50 mM Tris- $\mathrm{HCl}(\mathrm{pH} 8.5), 3 \mathrm{mM} \mathrm{MgCl}_{2}, 20 \mathrm{~mm} \mathrm{KCl}, 500 \mu \mathrm{g} / \mathrm{ml}$ bovine serum albumin, $2.5 \%$ (wt/vol) Ficol 400 and 0.4 unit of Taq polymerase. Samples were amplified 
by a rapid cycling system of low heat capacity based on heat transfer by hot air to samples that was contained in glass capillary tubes (1605 Air Thermo-Cycler/ Idaho Technology). Samples were processed by 35 cycles of denaturation at $94^{\circ} \mathrm{C}$ for $5 \mathrm{sec}$, annealing (primer sequences and other characteristics such as annealing temperature for each DNA marker are shown in Table 1) for $5 \mathrm{sec}$, and elongation at $72^{\circ} \mathrm{C}$ for $30 \mathrm{sec}$.

Genotyping and linkage analysis. Electrophoresis was carried out on a minisized $(8 \times 7 \mathrm{~cm}) 10 \%$ polyacrylamide gel for about $30 \mathrm{~min}$ and the gel was stained with ethidium bromide. Observed heterozygosity for each marker was calculated from the CEPH parents and unrelated Japanese individuals. When using the mini-sized acrylamide gels, it is usually hard to differentiate more than two alleles in any families. Therefore, we chose CEPH families showing only 2 allele systems. The LINKAGE (ver. 5.1) computer programs (Lathrop et al., 1985) were used to construct a linkage map. Pairwise lod scores were calculated among our 4 $(\mathrm{CA})_{\mathrm{n}}$ markers and other DNA markers of chromosome 8 from the CEPH data base ver. 6.0 .

\section{RESULTS}

Identification and characterization of $(C A)_{n}$ repeats

CISS hybridization using the entire PCR products from 8 p11.2-p22 region as a pool of probes showed fluorescence signals corresponding to the microdissected region (data not shown). We have developed a simplified system to detect $(\mathrm{CA})_{\mathrm{n}}$ repeat polymorphisms in PCR products. Since recirculating hot air system can quickly change temperature of a small volume sample containing in a glass capillary tube, whole PCR running times is less than $30 \mathrm{~min}$ for 25 cycles. We have been able to try PCR many times to determine an optimum condition. If primers were selected to produce PCR products of approximately $100 \mathrm{bp}$, differences in length of PCR products could be easily recognized by $10 \%$ polyacrylamide gel electrophoresis after ethidium bromide staining (Fig. 1). Slippage band(s) may help to differentiate homozygosity from heterozygosity.

Of a total of 160 sequenced clones, 104 had more than $10(\mathrm{CA})_{n}$ repeats. The remaining 56 clones were discarded because of unreliable sequences or misplaced microsatelites. Out of 104 clones, 46 were independent each other because 58 clones were isolated more than twice. Primer pairs were synthesized for 30 clones but suitable primer sequences were not found on the remaining 16 clones. Polymorphism of each microsatellite was assayed by PCR products derived from 6 to 9 unrelated Japanese individuals. Finally, we have isolated 24 polymorphic clones with $(\mathrm{CA})_{\mathrm{n}}$ repeat sequences. Seven of 24 clones may have been closely linked to the WRN locus by the result of homozygosity mapping (Kihara et al., unpublished data). In this study, four polymorphic $(\mathrm{CA})_{n}$ repeat markers were analyzed in detail. Table 1 shows allele sizes of these polymorphic markers (MS8-2, MS8- 

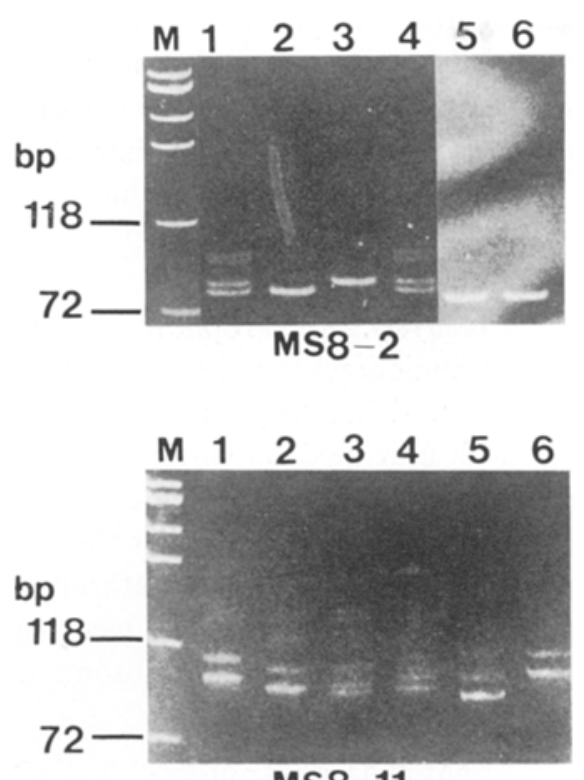

MS8-11

Fig. 1. Polyacrylamide gel electrophoresis of PCR products from unrelated individuals for MS8-2 and MS8-11 after ethidium bromide staining. In MS8-2, lanes 2, 3, 5,6 for MS8-2 were homozygotes, while lanes 1, 4 were heterozygotes. In MS811. lanes 1, 2, 5, 6 were homozygotes, while lanes 3, 4 were heterozygotes.

Table 1. Characteristics of 4 microsatellite markers from a microdissection library of 8p11.2-p22.

\begin{tabular}{|c|c|c|c|c|c|}
\hline Locus & Repeat sequence & Oligo sequence & $\begin{array}{l}\text { Anneal } \\
\left({ }^{\circ} \mathrm{C}\right)\end{array}$ & $\begin{array}{l}\text { PCR } \\
\text { product } \\
\text { (bp) }\end{array}$ & $\begin{array}{c}\% \text { Heterozygosity } \\
\text { Caucasian/ } \\
\text { Japanese }\end{array}$ \\
\hline \multirow[t]{2}{*}{ MS8-2 } & $\begin{array}{l}(\mathrm{CA})_{5} \mathrm{GA}(\mathrm{CA})_{3} \mathrm{GA} \\
(\mathrm{CA})_{10} \mathrm{GT}(\mathrm{CA})_{6}\end{array}$ & $\begin{array}{l}\text { CAGCCTCTAA- } \\
\text { GACAAGTCAAA }\end{array}$ & $60^{\circ} \mathrm{C}$ & 108 & $57.1 / 54.5$ \\
\hline & & $\begin{array}{l}\text { TCCCTGGGCA- } \\
\text { ACTGTGTG }\end{array}$ & & & \\
\hline \multirow[t]{2}{*}{ MS8-10 } & $\begin{array}{l}(\mathrm{CA})_{9} \mathrm{CG}(\mathrm{CA})_{4} \\
\mathrm{CTCA}(\mathrm{CT})\end{array}$ & $\begin{array}{l}\text { ACATTTGTCTA- } \\
\text { GGATCGATAAG }\end{array}$ & $50^{\circ} \mathrm{C}$ & 106 & $64.3 / 66.7$ \\
\hline & & $\begin{array}{l}\text { CTTTTGCACTA- } \\
\text { TTCTAAAACCTA }\end{array}$ & & & \\
\hline \multirow[t]{2}{*}{ MS8-11 } & $(\mathrm{AC})_{4} \mathrm{G}(\mathrm{CA})_{2} \mathrm{CG}(\mathrm{CA})_{6}$ & $\begin{array}{l}\text { GCATCAGAAA- } \\
\text { TTTGCTCAGAG }\end{array}$ & $52^{\circ} \mathrm{C}$ & 80 & $32.0 / 30.0$ \\
\hline & & $\begin{array}{l}\text { TACACTCTTTA- } \\
\text { AATGTATGTGCA }\end{array}$ & & & \\
\hline \multirow[t]{2}{*}{ MS8-171 } & $(\mathrm{CA})_{1 \mathrm{i}}$ & $\begin{array}{l}\text { ATGATGTTGTA- } \\
\text { TTTAGAAAATC }\end{array}$ & $47^{\circ} \mathrm{C}$ & 91 & $25.0 / 74.1$ \\
\hline & & $\begin{array}{l}\text { CTAGCTCTA- } \\
\text { ATGGTTTTATGT }\end{array}$ & & & \\
\hline
\end{tabular}


10, MS8-11, and MS8-171), oligonucleotide primer sequences, annealing temperatures for PCR amplifications, and heterozygosities calculated from the CEPH members as Caucasians and from unrelated Japanese individuals. All microsatellites but MS8-171 have almost the same \% heterozygosity values between the Caucasian and the Japanese.

\section{Linkage analysis}

Because the PCR products were separated on a mini-sized polyacrylamide gel to be visualized with ethidium bromide staining, it seemed usually hard to differentiate more than two alleles in one family. Therefore we chose CEPH families which show 2 allele systems. For linkage analysis, we genotyped five $(102,104$, 1332 , 1345, 1423) families using MS8-2, eleven (37, 104, 884, 13291, 13293, 1333, $1340,1346,1375,1413,1424)$ families using MS8-10, eight $(35,66,102,104,884$, $1331,1375,1424)$ families using MS8-11, and five $(17,37,104,1331,1416)$ families using MS8-171. Table 2 shows the result of a two-point linkage analysis. Four markers were divided into two linkage groups. The first group consisted of MS810 and MS8-11, close to the LPL marker, while MS8-2 and MS8-171 were the second group which was linked to the ANK1 marker. Two markers within each group were relatively closely linked each other but unlinked to markers from the other group.

\section{DISCUSSION}

Thus far in our work aimed at the molecular cloning of the WRN gene, we have combined an improved method of chromosome microdissection with a simplified method of mapping microsatellite markers. To the best of our knowledge this paper is the first to report the isolation of $(\mathrm{CA})_{\mathrm{n}}$ repeat markers from a microdissected library. Recently, more than a thousand new $(\mathrm{CA})_{\mathrm{n}}$ repeat DNA markers with an average resolution of about $5 \mathrm{cM}$ have been made available by Weissenbach et al. (1992). However, there are still genomic regions that are not well covered with useful markers. We have isolated 7 microsatellites from the WRN region ranging from ANK1 to LPL. The genetic distance is about $31.3 \mathrm{cM}$ based on the data presented by Tomfohrde et al. (1992), who isolated 3 microsatellites in this

Table 2. Pairwise recombination estimates between adjacent loci.

\begin{tabular}{lclr} 
Locus & $\begin{array}{c}\text { Lod scores }(\theta) \text { between } \\
\text { adjacent microsatellites }\end{array}$ & \multicolumn{2}{c}{$\begin{array}{c}\text { Lod scores }(\theta) \text { between } \\
\text { microsatellites and other markers }\end{array}$} \\
\hline MS8-10 & $1.57(0.1350)$ & LPL3GT & $17.04(0.0930)$ \\
MS8-11 & & LPL3GT & $7.03(0.0960)$ \\
\hline MS8-2 & $15.86(0.1100)$ & ANK1A,B & $3.12(0.0520)$ \\
MS8-171 & & ANK1A,B & $4.21(0.0000)$ \\
\hline
\end{tabular}


area. Weissenbach et al. (1992) mapped about 10 markers unevenly spaced through this region. Our microdissected microsatellites in this region have enhanced the resources available to make a refined map useful for positional cloning.

To detect microsatellite polymorphisms it is usually required to use PCR primers labeled with a radioisotope or else fluorescent dyes and an apparatus for long-gel electrophoresis. This is time consuming and labor intensive in either case. By employing two modified methods, we have developed a simplified detection system for microsatellite PCR products. First, a thermal cycler using recirculated hot air speeds up the treatment of $10 \mu \mathrm{l}$ samples so that total amplification time is less than 30 min for 25 cycles. In a single cycle lasting less than a min, denaturing takes $5 \mathrm{sec}$, annealing $5 \mathrm{sec}$, and elongation $30 \mathrm{sec}$ to produce PCR products for ANK1. The small sample volume allows us to save on Taq polymerase as well as the amount of human DNA samples needed. Because of the shortened PCR cycle, we have been able to search for optimum conditions more conveniently by repeating the PCR procedure many times. Second, if the PCR product is about 100 base pairs, we can detect as little as a 2 base pair difference in products employing $10 \%$ polyacrylamide gel electrophoresis after ethidium bromide staining (unpublished data). Slippage bands help to differentiate homozygotes from heterozygotes.

One limitation we encountered was that when a polymorphism had more than three alleles segregating in a family we had to exclude that family because it was not usually to distinguish multiple bands with mini-polyacrylamide gel electrophoresis. To handle these families with more than three segregating alleles at a locus, we used long-sized gels. One of our 7 new microsatellites from the WRN region, D8S360 (MS8-8), had 12 alleles and 89\% heterozygosity. We mapped this marker by a more conventional method (Kamino et al., 1993). In order to help to narrow the region in which the WRN gene is located, we are examining affected first cousins at the nearby microsatellite loci for homozygosity as a clue to identify markers closest to the WRN locus.

Acknowledgments This work was partly supported by a Grant-in-Aid for a Creative Basic Research (Human Genome Program) from the Ministry of Education, Science and Culture of Japan, and a grant of the Research Project on Health and Aging.

\section{REFERENCES}

Deng H-X, Yoshiura K, Dirks RW, Harada N, Hirota T, Tsukamoto K, Jinno Y, Niikawa N (1992): Chromosome-band-specific painting: Chromosome in situ suppression hybridization using PCR products from a microdissected chromosome band as a probe pool. Hum Genet 89: $13-17$

Goto M, Rubinstein M, Weber J, Woods K, Drayna D (1992): Genetic linkage of Werner's syndrome to five markers on chromosome 8. Nature 335: 735-738

Hirota T, Tsukamoto K, Deng H-X, Yoshiura K, Ohta T, Tohma T, Kibe T, Harada N, Jinno $Y$, Niikawa $N$ (1992): Microdissection of human chromosomal regions 8q23.3-q24.11 and 
2q33-qter: construction of DNA libraries and isolation of their clones. Genomics 13: 349-354

Jinno Y, Harada N, Yoshiura K, Ohta T, Hirota T, Tsukamoto K, Deng H-X, Oshimura M, Niikawa N (1992): A simple and efficient amplification method of DNA with unknown sequences and its application to microdissection/microcloning. J Biochem 112: 75-80

Kamino K, Nakura J, Kihara K, Lin Ye, Nagano K, Miki T, Ohta T, Jinno Y, Niik awa N, Ogihara $T$ (1993): Population variation in the dinucleotide repeat polymorphism at the D8S360 locus. Hum Mol Genet 2: 1751

Kibe T, Tsukamoto K, Hirota T, Yoshiura K, Ohta T, Tohma T, Tamura T, Jinno Y, Niikawa $\mathrm{N}$ (1992): Isolation of 2 novel RFLP markers and their localization at $2 \mathrm{q} 35$ by microdissection and subsequent enzymatic amplification. Jpn $\mathfrak{J}$ Human Genet 37: 263-270

Lander ES, Botstein D (1987): Homozygosity mapping: A way to map human recessive traits with the DNA of inbred children. Science 236: 1569-1570

Lathrop GM, Lalouel JM, Julier C, Ott J (1985): Multilocus linkage analysis in humans: Detection of linkage and estimation of recombination. Am J Hum Genet 37: 482-498

Schellenberg DG, Martin GM, Wijsman EM, Nakura J, Miki T, Ogihara T (1992): Homozygosity mapping and Werner's syndrome. Lancet 339: 1002

Tomfohrde J, Woods S, Schertzer M, Wagner MJ, Wells DE, Parrish L, Salder LA, Blanton SH, Daiger SP, Wang Z, Wilkie PJ, Weber JL (1992): Human chromosome 8 linkage map based on short tandem repeat polymorphisms: Effect of genotype errors. Genomics 14: 144-152

Weissenbach J, Gyapay G, Dib C, Viginal A, Morissentte J, Millasseau P, Vaysseix G, Lathrop M (1992): A second-generation linkage map of the human genome. Nature 359: 794-801 